\title{
KOMPLEK BIARA KOTA KONTEMPORER BERBASIS WISATA DI KECAMATAN TAMANSARI
}

\author{
Tri Putra Bhakti ${ }^{1)}$, Petrus Rudi Kasimun ${ }^{2)}$ \\ 1) ) Program Studi S1 Arsitektur, Fakultas Teknik, Universitas Tarumanagara, matthewtpb11@gmail.com \\ 2) Program Studi S1 Arsitektur, Fakultas Teknik, Universitas Tarumanagara, Petrusk@ft.untar.ac.id
}

\begin{abstract}
Abstrak
Biara sebagai bangunan pewadah kehidupan monastik, memiliki sejarah panjang dan telah berkembang selama 18 abad. Dalam perkembangannya, arsitektur biara memiliki nilainilai esensial yang terus dipertahankan, namun di sisi yang lain kompleksitas arsitektur biara terus meningkat karena penyisipan nilai atau injeksi program yang baru didalamnya sebagai upaya untuk beradaptasi terhadap perubahan konteks. Proyek ini merupakan perancangan biara dengan injeksi kegiatan pariwisata berbasis spiritual didalamnya, dimana intervensi pariwisata menghasilkan aktifitas dan kondisi yang berbeda dan menuntut rancangan biara kontemporer yang sesuai. Sebagai bangunan spiritual dimana fungsionalitas dan pengalaman ruang adalah sama penting, digunakan dua metode yang berintikan pada teori tipe. Pertama untuk fungsionalitas, mengamati evolusi tipe bangunan biara yang dikomparasikan dengan pengamatan perkembangan kehidupan monastik sebagai inti yang membentuk biara sendiri untuk mencari esensi dari biara dan menemukan bagian rancangan yang perlu diubah. Kedua untuk pengalaman ruang, pencarian arke-tipe pemacu persepsi kesakralan dan teritori lingkupan religi melalui pengamatan evolusi tipe bangunan, yang kemudian disusun kembali sesuai dengan teoriteori pembentukan ruang sakral. Diharapkan hasil perancangan dapat menjadi pewadah kegiatan mindfulness yang memudahkan pengunjung mendapatkan relaxation response (Benson, 1993) yang bermanfaat meningkatkan daya fokus, ketenangan dan produktifitas. Bagi kota Jakarta sendiri, memberikan dampak positif secara tidak langsung bagi perkembangan ekonomi kota, dan meningkatkan atraksi lintasan wisata religi di Kecamatan Tamansari dan Kecamatan Gambir, Jakarta.
\end{abstract}

Kata kunci: Arke-tipe, Biara kontemporer, mindfulness, pariwisata, tipe

\begin{abstract}
Monastery as a building vessel of monastic life, has a long history and has been evolving for 18 centuries. In architecture development, monastery has particular essential values that have to be maintained. In the other hand, monastery's complexity in architecture keep on rising due to new values insertion and program injections as an attemp to addapt towards context transformation. This project is a monastery building injected with tourism in spiritual based, where tourism intervention produce diverse activity in different context and demand for a suitable monastry design. As a spiritual building where functionality and spatial experience are equally important, two different methods which are focus on theory of 'type' are used. The first one for functionality, to observe the type evolution of monastery and compare it with the development of monastic life as the main element to build its own building, to search the essense of monastery, and to discover several parts that need transformation. The second for spatial experience, to seek archetype to boost the perception of sacredness and religion territory through type evolution observation, which then rearranged in accordance with the formation of sacred place theories. The result of the design process is expected to accommodate mindfulness activity which help the visitors to reach the state of relaxation response (Benson, 1993) to gain focus, calm, and productivity. For Jakarta city, to present positive impact indirectly for the economy development by increasing religious tourism trajectory in Tamansari and Gambir subdistrict in Jakarta.
\end{abstract}

Keywords: archetype, Contemporary Monastery, mindfulness, tourism, type 


\section{PENDAHULUAN}

\section{Latar Belakang}

Kota padat terutama di negara berkembang cenderung memiliki keadaan fisik, sosial, dan ekonomi yang berpotensi memberikan dampak buruk bagi kesehatan psikis penduduknya. Biara berbasis wisata merupakan salah satu sarana penarikan diri yang menyeimbangi keadaan tersebut dengan mengupayakan pengobatan psikis melalui kegiatan-kegiatan berbasis mindfulness. Namun di Kota Jakarta, secara dominan biara "terdampar" pada karakter tipe bangun blok persegi tunggal layaknya sebuah rumah-toko (ruko). Gen-gen arsitektur esensial bangunan biara yang telah berkembang 18 abad diabaikan. Alhasil Akibat simplifikasi berlebihan tersebut pengalaman ruang dan hal-hal krusial bangunan biara lainya tidak tercipta dengan baik dan mengurangi tingkat kondusifitasnya yang berujung pada perusakan pengalaman kegiatan penarikan diri itu sendiri. Oleh karena itu, pengadaan biara kedalam kota perlu mengadopsi bentuk perancangan bangunan yang baru.

\section{Permasalahan Arsitektur}

Sebagai biara yang mewadahi kegiatan wisata spiritual berbasis mindfulness, perlu untuk menerapkan peancangan yang dapat memacu perhatian pengunjung terhadap konteks sekitarnya yang sedang berlangsung. Pengunjung harus fokus terhadap ruang-ruang, suara, kegiatan, disekitarnya yang "kontras" dengan kehidupan sehari-hari. Oleh karena itu, untuk menghasilkan kondusifitas kegiatan yang berlangsung didalam biara, rancangan perlu perlu untuk memiliki atraksi pengalaman yang tinggi dan mampu mengisolasi pengunjung biara dari konteks luar bangunan yang langsung berhadapan dengan kota.

\section{KAJIAN LITERATUR}

Berikut penjelasan singkat beberapa teori yang digunakan dalam tahap diskusi.

\section{Tipologi}

Tipologi dapat dibagi menjadi dua inti yaitu genre (fungsi) dan tipe (bentuk). genre dan tipe adalah terpisah namun selalu berkesenambungan. Seiring berjalannya waktu, bentuk dapat berubah dan hal ini mengindikasikan suatu perubahan yang terjadi pada genre. Demikian dalam proyek ini pengamatan demikian dipergunakan untuk melakukan verifikasi bentuk bangun yang perlu dipertahankan dan diubah. Teori Tipe dapat berdiri sendiri dan bermanfaat secara maksimal sebagai alat heirudistis (Lee, 2012). Berikut beberapa pemahaman tipe:

1. Tipe dominan: tipe yang berpengaruh dan paling menonjol. dalam konteks ini merupakan yang paling tipikal dan umum untuk semua

2. Proto-tipe: tipe yang pertama kali muncul atau digunakan terhadap sesuatu.

3. Stereo-tipe: tipe bangun yang paling banyak dipakai terhadap suatu fungsi bangunan atau aspek lainnya.

4. Arke-tipe: tipe primitif yang telah ada sejak dahulu, sehingga dapat dikatakan ideal. Bertahannya sejak dahulu menghasilkannya sebagai tempat persemayaman suatu memori (hierofani).

Teori tipe berlaku tidak hanya pada skala massa bangunan secara keseluruhan. Konsep tipe ini berlaku pada setiap skala pembentukan bangunan dimulai dari bangunan keseluruhan, kompilasi ruangan, ruangan, dan elemen arsitektur seperti dinding, lantai, plafond, dst (Koolhaas \& Boom, 2014). Pemahaman ini yang kemudian digunakan dalam proses perancangan, dimana dilakukan secara generatif atau dari satuan terkecil yang membentuk satuan yang lebih besar dan seterusnya hingga kesatuan komplek biara.

\section{Fenomenologi}

Kata fenomenologi berasal dari kata fenomena yang berarti "apa yang ada atau terlihat", mengindikasikan suatu pengalaman.dalam teori fenomenologi pengalaman tersebut 
dikembangkan kesetiap lima indera manusia. fenomenologi arsitektur secara mendasar, mengupayakan bangunan yang dapat memberikan pengalaman multi-sensory yang terhubung dengan manusia secara fisik, emosional, dan intelektual (Barron, 2014).

\section{Tipe dan Fenomenologi}

Teori fenomenologi diperkenalkan dengan ilmu arsitektur untuk pertamanya kali oleh Martin Heidegger. Teori ini pun memiliki "keturunan" yang berhubungan dengan konsep "tipe" dari teori tipologi. Fenomenologi, dikembangkan kedalam skala urban oleh Christian Noberg Schulz dengan teori Genius Loci (Spirit of Place), dimana kehadiran dari elemen-elemen kota membentuk pemaknaan suasananya tersendiri oleh pengunjungnya. Konsep tersebut sesuai dengan pemahaman Aldo Rossi dimana tipe dapat menjadi tempat bersemanyamnya memori atau dapat dikatakan sebagai locus (Rossi, 1982). Hal tersebut mengkonfirmasi bahwa objek hierofani (Eliade, 2002) atau arke-tipe (Hoffman, 2010) bisa terdapat pada elemen arsitektur pada tipe bentuk yang tertentu.

\section{METODE}

Untuk mencapai kondusifitas, proyek sebagai bangunan spiritual dimana fungsionalitas dan pengalaman ruang adalah sama penting, digunakan dua metode yang berintikan pada teori tipe. Pertama untuk fungsionalitas, mengamati evolusi tipe bangunan biara yang dikomparasikan dengan pengamatan perkembangan kehidupan monastik sebagai inti yang membentuk biara sendiri untuk mencari esensi dari biara dan menemukan bagian rancangan yang perlu diubah mengikuti keadaan aktifitas biara yang baru sebagai pewadah kegiatan wisata berbasis mindfulness. Kedua untuk pengalaman ruang, pencarian bentuk stereotomik dan komposisi (arke-tipe) yang memacu persepsi kesakralan (Eliade, 2002) dan teritori lingkupan religi melalui pengamatan evolusi tipe bangunan, yang kemudian disusun kembali sesuai dengan teori-teori pembentukan ruang sakral.

\section{DISKUSI DAN HASIL}

Untuk memahami perancangan biara, perlu untuk memahami latar belakang perancangan biara dan perkembangnnya. Diagram berikut (gambar 1) merupakan riset terhadap perkembangan kehidupan monastik. Dimana dalam perkembangn kehidupan monastik terdapat hal yang terus bertahan namun memiliki pengolahan yang berubah-ubah. Salah satunya adalah pemecahan bagian kehidupan monastik :

1. St. Benedictine (540): kehidupan doa bersama, doa individual, dan aktivitas berkerja.

2. Antonie Guillmont (1953): kehidupan soliter, dan komunal.

3. Le Corbusier (1962): kehidupan individual, kehidupan kolektif, kehidupan spiritual.

4. Luca Morosetti (2015): kehidupan individual, kehidupan kolektif, kehidupan spiritual, dan berkerja (Morosetti, 2015).

Padangan diatas menunjukan pola bahwa kehidupan monastik dapat dibagi kedalam empat bagian yaitu individual, kolektif, spriritual, servis. Keempat bagian ini adalah terpisah dan memiliki prioritasnya masing-masing sehingga merepresentasikan empat kategori program bangunan yang memiliki kebutuhan bentuk ruang, bentuk massa (kompilasi ruangan), dan peletakan ruang yang berbeda. Selain itu pertemuan diantara satu ruang dan ruang lain memerlukan penggunaan media pemisah dengan tingkat soliditas yang berbeda.

Untuk mendapatkan penyikapan rancangan yang konkrit untuk menjawab prinsip-prinsip yang didapat dari riset monastik sebelumnya, dilakukan pembedahan tipologikal bangunan biara (gambar 2). Salah satu prinsip yang menjadi struktur bangunan adalah pemisahan jalur sirkulasi menuju ruang individual dan sakral yang terpecah dari ruang komunal utama bangunan. Untuk peletakan ruang individual terletak pada titik pencapaian yang terjauh dari ruang komunal sedangkan ruang bersifat spiritual terletak berdampingan dengan ruang komunal atau dengan luar tapak. Namun, terkadang ruang bersifat individual memiliki jarak yang sama dengan ruang 
lain. hal ini menghasilkan upaya isolasi yang berbeda cara, yaitu dengan adopsi bentuk bangun yang sesuai. Yaitu bentuk bangun hasil kompilasi ruang bersifat individual berbentuk " $L$ " atau bentukan lain yang berpotensi menciptakan pemecahan antara sirkulasi utama dan sekunder yang atau prinsip sirkulasi kuldesak sehingga meminimalisir sirkulasi dan potensi gangguan. Sedangkan bentuk bangun massa ruang bersifat spiritual cenderung memiliki massa blok yang berbeda dari blok massa lainnya dan sering memiliki proporsi monumental apabila dibandingkan dengan skala tubuh manusia. Hal ini bertujuan menandakan bangunan publik dan memberikan pengalaman atau persepsi sakral bagi orang yang berada didalamnya.

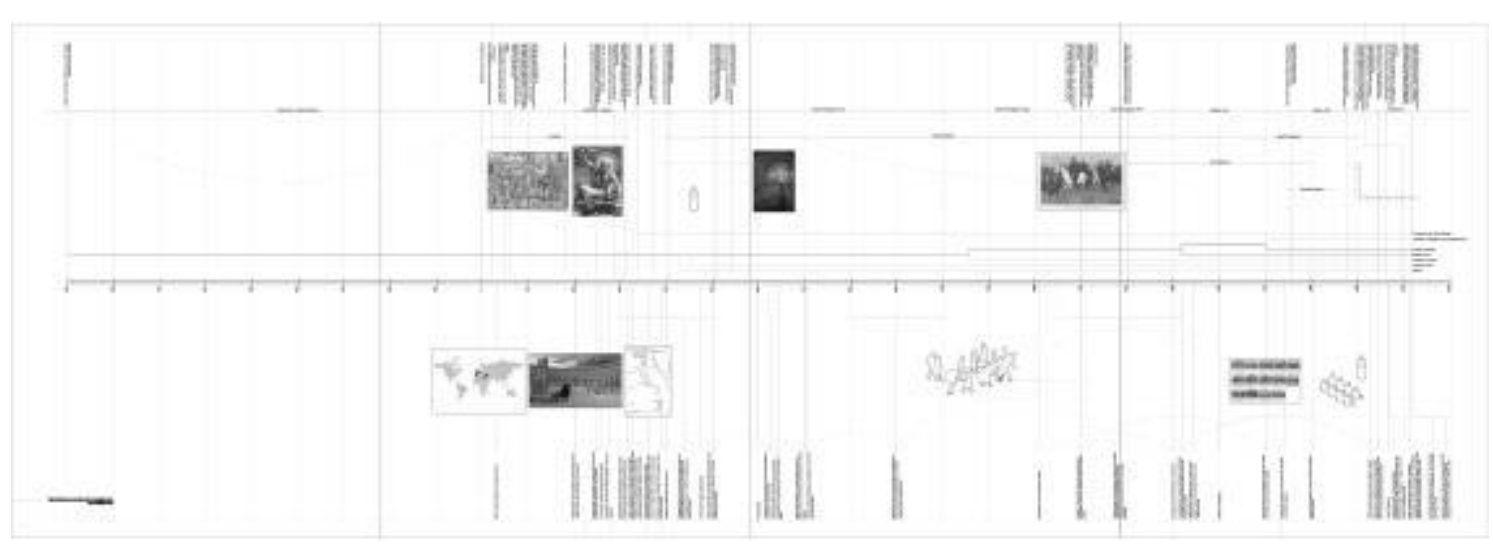

Gambar 1. Riset perkembangan monastik

Selain mengamati bentuk dan hubungannya dengan fungsionalitas, pembedahan juga mencoba membongkar beberapa strategi penciptaan suasana dan performa bangunan yang terkandung didalamnya. strategi tersebut adalah strategi lansekap, soliditas - prositas, dan arke-tipe.

Strategi lansekap dari pada bangunan biara didominasi berbentuk kotak dan dikelilingi massa bangunan (kloister). Hal ini terjadi karena perintah suatu ordo yang kemudian menjadi ciri khas biara dan menyimbolkan paradise garden. Dapat dikatakn bentuk yang tidak dilatarbelakangi kebutuhan. Alhasil banyak terjadi perubahan seperti multi-kloister, kloister vertikal, dsb. Hal ini memungkinkan perancangan untuk memberikan komposisi lansekap yang baru dan sesuai dengan biara berbasis wisata di kota.

Soliditas - porositas bangunan mengartikan pergerakan angin, kelembaban, serta interaksi antar ruang. Rata-rata tingkat soliditas secara denah dan potongan adalah $50 \%$.

Kemudian, riset pembedahan tipologikal yang menunjukan pola penggunaan bentukan stereotomik (tipe) yang berulang sejak kemunculannya. Tipe-tipe ini lah yang merupakan arketipe tempat bersemanyam-nya persepsi ruang sakral atau teritori bangunan biara. Hal ini terlihat pada setiap skala pembentukan bangunan dari skala keseluruhan bangunan, kompilasi ruangan, ruangan, dan elemen arsitektur. Diekstraklah tipe-tipe yang berulang dan menjadi pola bangunan biara selama proses pembedahan tipologikal. Adapun pembedahan arke-tipe itu berfokus pada tipe yang berperan sebagai gate, path, place yang merupakan rangkaian bentuk sakral (Hoffman, 2010). Selain fokus utama tersebut, pembedahan arke-tipe juga menemukan tipe bentuk yang menjadi media pemisah antar ruang yang mewadahi kegiatan dan ruang natural (penghijaun dan air). Pembedahan juga menemukan tipe-tipe yang digunakan untuk pemisahan antar ruang dengan perbedaan sifat (individual, kolektif, spirituan, servis). Salah satunya adalah dinding (building fabric) berbentuk " $\mathrm{i}$ " secara denah. Dimana memiliki strategi pemecahan ruang menjadi tiga bagian dengan hirarki kepublikan (ruang kolektif, sirkulasi, privat). Selain itu, banyak elemen arsitektur lainnya lagi yang ditemukan yang berpotensi memancarkan kesakralan maupun pemisah ruang antara lain adalah baris titik " ... . ", lengkungan setengah lingkaran (arc), arkade " : : : :" dll. 


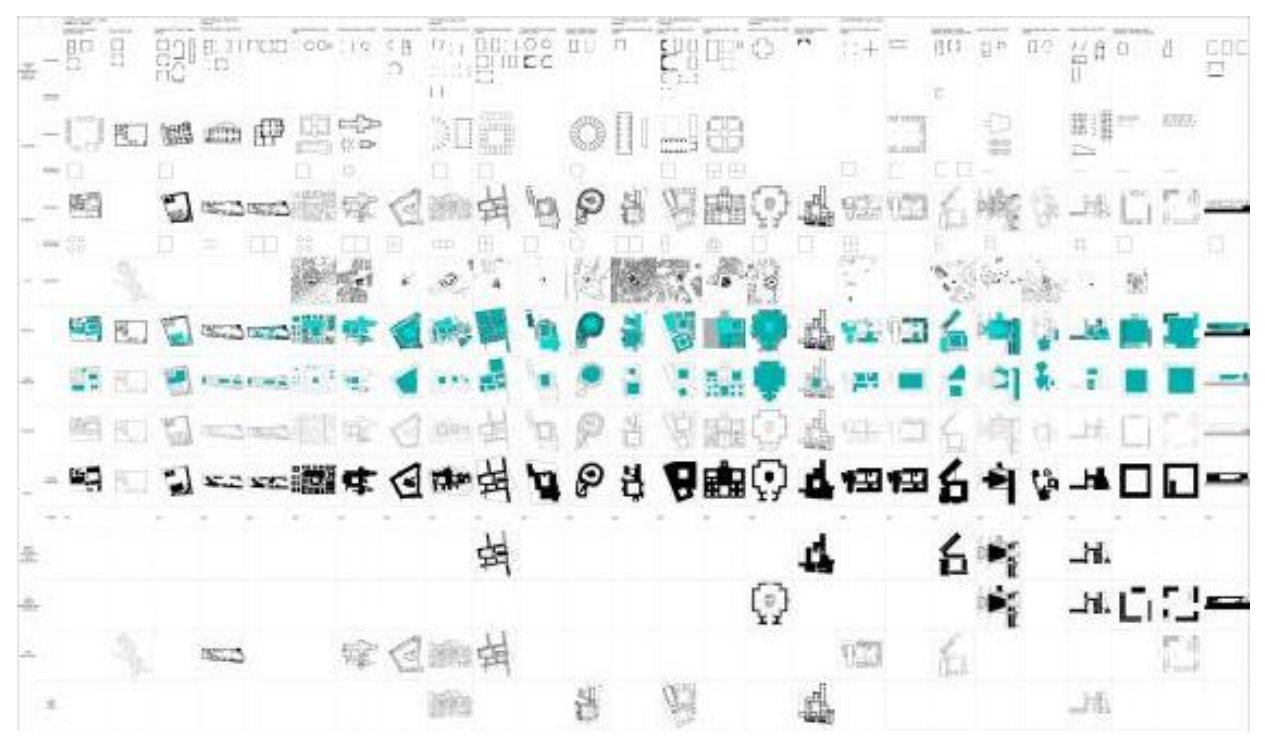

Gambar 2. Riset Pembedahan Tipologikal Bangunan Biara

Elemen-elemen hasil ekstrak pembedahan tipologikal tersebut diolah membentuk ruang yang memacu persepsi kesakralan dan sebagai media pembagian ruang yang sesuai. Fokus perangkaian tipe pemacu persepsi sakral berfokus pada rangkaian gate, path, place dan diikuti dengan peletakannya secara tunggal tanpa rangkaian secara tersebar di biara tanpa biara sebagai upaya pengalihan perhatian dan fokus pengunjung pada area sekitarnya dan untuk menciptakan suasana sakral secara menyeluruh disaat menyusuri bangunan. diagram (Gambar 3) merupakan letak tipe-tipe hasil ekstrak pembedahan tipologikal.

Diagram (Gambar 4) menunjukan denah lantai tiga dan empat sebagai yang didominasi program daripada biara. Merupakan hasil performa (figure ground, cloistered, letak unit sel, fasilitas bersama, natural resources, sirkulasi, dan organisasi zona bangunan (biara, kantor, gereja). bangunan yang terbentuk dengan mengaplikasikan keseluruhan konsep yang didapat dari riset perkembangan monastisisme dan pembedahan tipologikal.

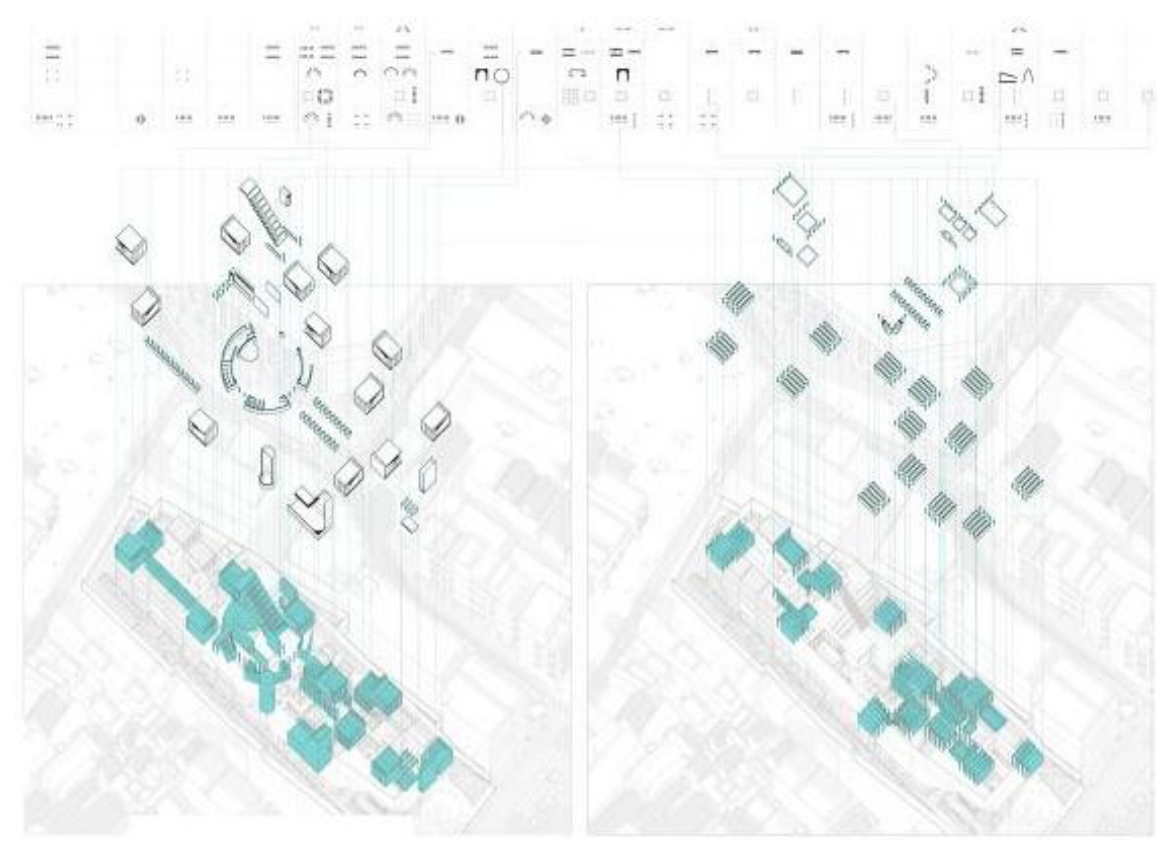

Gambar 3. Aksnonometrik pembongkaran Tipe Bangun 

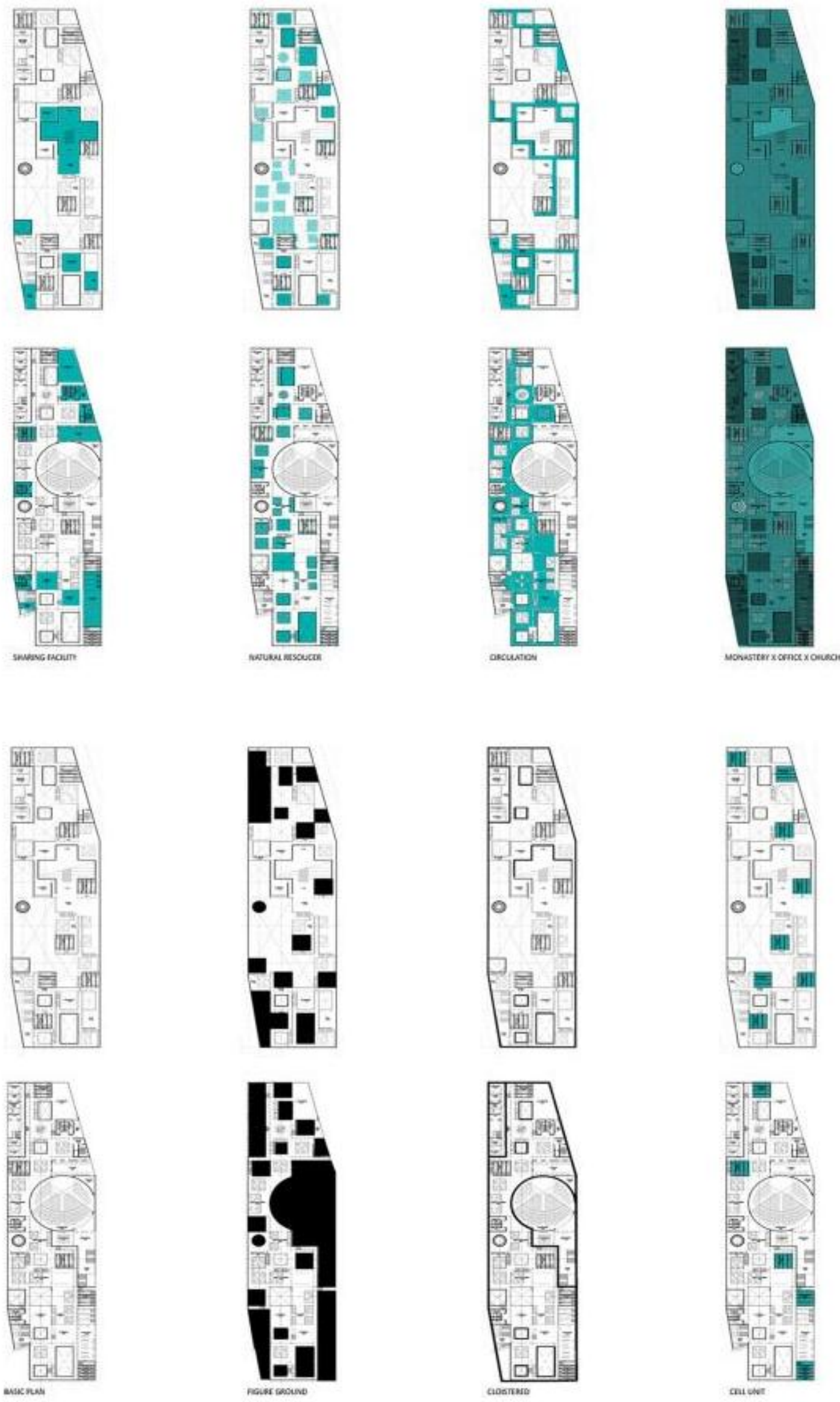

Gambar 4. Performa Hasil Akhir Perancangan 


\section{KESIMPULAN DAN SARAN}

Merancang bangunan religi adalah penting untuk mencermati fungsionalitas dan pengalaman ruang yang akan menentukan kondusifitas akitiftas didalamnya. Untuk merancangan biara berbasis wisata yang menajwab permasalah fungsionalitas, perlu untuk memperhatikan banyak hal dimulai dari pengolahan organisasi dan keterhubungan antar ruang dengan sifat individual, kolektif, spiritual, dan servis. Selain itu, Permutasi pertemuan antar ruang dengan sifat berbeda tersebut memerlukan penyikapan yang berbeda satu sama lain. Tipe bentuk terutama bentuk massa bagian sebagai perwujudan dari keempat ruang dasar kehidupan monastik dimana setiap memiliki perbedaan performa dan potensi untuk mewadahi kegiatan berbeda.

Di sisi lain, Untuk menghasilkan biara dengan pengalaman ruang yang maksimal, perlu untuk mengadopsi arke-tipe yang menjadi tempat beremayamnya persepsi kesakralan. Kemudian dirangkai sesuai dengan susunan yang membentuk lintasan sehingga menghasilkan penyusunan yang bercerita disetiap orang memasuki segmen yang baru dan mengalaminya melalui panca inderanya. Dengan begitu dapat tercapailah rancangan yang dapat memacu pengunjung untuk fokus sepenuhnya terhadap keadaan sekitar yang dialaminya (mindfulness).

\section{UCAPAN TERIMA KASIH}

Terima kasih kepada semua pihak terutama dosen UNTAR yang telah membantu dalam menyelesaikan naskah penelitian ini.

\section{REFERENSI}

Barron, A. C. (2014). A Sentimental Typology. Tulane School of Architecture.

Benson, H. (1993). The Relaxation Response. Harper Collins.

Eliade, M. (2002). Sakral dan Profan. Fajar Pustaka Baru.

Hoffman, D. R. (2010). Seeking the Sacred in Contemporary Religious Architecture. Kent State University Press.

Koolhaas, R., \& Boom, I. (2014). Elements of Architecture. Marsilio.

Lee, C. C. (2012). The Fourth Typology, Dominant Type and the Idea of the City. TU Delft. Morosetti, L. (2015). The contemporary monastery : Application and adaptation of the monastic typology to contemporary collective housing. TU Delft.

Rossi, A. (1982). The Architecture of the City. MIT Press. 